\title{
Presence of Parvovirus B19 but Not Herpesvirus Genome in Acute Skin Rash after Allogeneic Stem Cell Transplantation Correlates with Outcome
}

\author{
Thomas Weber ${ }^{a}$ Andreas Schmidberger ${ }^{a}$ Kinga Ligeti $^{\mathrm{a}}$ Marcus Bauer $^{\mathrm{b}}$ \\ Andreas Rosenwald ${ }^{c}$ Lutz P. Müller ${ }^{a}$ \\ a Department of Hematology and Oncology, University Hospital Halle (Saale), Martin Luther University \\ Halle-Wittenberg, Halle (Saale), Germany; ${ }^{b}$ Institute of Pathology, University Hospital Halle (Saale), Martin Luther \\ University Halle-Wittenberg, Halle (Saale), Germany; ' Institute of Pathology, University Hospital Würzburg, \\ Würzburg, Germany
}

\section{Keywords}

Stem cell transplantation · Skin rash · Graft-versus-host disease · Polymerase chain reaction · Herpes viruses .

Parvovirus B19

\begin{abstract}
Introduction: Skin rash is a first symptom of acute graft-versus-host disease (GvHD) after allogeneic stem cell transplantation (ASCT) but can also be caused by viruses. The relevance of virus DNA analyses in skin rash for diagnosis and clinical outcome is unknown. Objectives: To record the frequencies of detection of herpes and parvovirus B19 (ParvoB19) DNA in skin rash within 100 days after ASCT and to analyze their relevance for diagnosis, clinical course, and non-relapse mortality (NRM). Methods: We retrospectively identified 55 patients with virus DNA analysis for CMV, EBV, HHV6, HHV8, HSV, VZV, or ParvoB19. We assessed the rate of virus DNA detection and studied associations with histological diagnosis, virus DNA from concomitantly analyzed blood, clinical presentation, exanthema treatment, and NRM. Results: CMV, EBV, HHV6, HHV8, HSV, VZV and ParvoB19 DNA were detected in $12.5,11.8,10,0,0,2.9$, and
\end{abstract}

karger@karger.com www.karger.com/aha

Karger $\stackrel{\text { ' }}{5}$

GOPEN ACCESS
(C) 2020 The Author(s)

Published by S. Karger AG, Basel

This is an Open Access article licensed under the Creative Commons Attribution-NonCommercial-4.0 International License (CC BY-NC) (http://www.karger.com/Services/OpenAccessLicense), applicable to the online version of the article only. Usage and distribution for commercial purposes requires written permission.
$26.7 \%$ of exanthemas. Histopathological diagnosis was not associated with virus polymerase chain reaction (PCR) results. Detection of CMV, EBV, or HHV6 DNA but not ParvoB19 in skin and blood was associated with PCR results $(p=0.016$; $p<0.001 ; p=0.067 ; p=$ n.a.). Detection of CMV, EBV, HHV6, or ParvoB19 DNA in the skin was not significantly associated with patient, ASCT, or GvHD characteristics. Detection of ParvoB19 but not herpes virus DNA was associated with less immunosuppressive treatment $(p=0.015)$ and lower NRM ( $p=$ 0.041). In multivariate analyses, detection of ParvoB19 was associated with a lower NRM. Conclusions: Detection of ParvoB19 DNA in exanthema after ASCT might be associated with lower NRM.

(c) 2020 The Author(s)

Published by S. Karger AG, Basel

\section{Introduction}

Despite many improvements over the last decades, transplant-related non-relapse mortality (NRM) after allogeneic stem cell transplantation (ASCT) is still around $15 \%$ for matched unrelated donor transplants $[1,2]$. In the first months after ASCT, acute graft-versus-host disease 
(aGvHD) has the highest impact on NRM with a mortality rate of $40-50 \%$ [3]. In most cases, skin rash is the first symptom of aGvHD [4,5]. However, skin rashes until day 100 after ASCT can have very different causes, such as viral infections, drug allergies, radiation dermatitis due to total body irradiation, or engraftment syndrome [6].

Skin rash can be the first and even the only clinical sign of viral reactivation or primary infection, especially due to herpes virus such as CMV, EBV, HHV6, HHV8, HSV, and VZV [7-9]. These reactivations are associated with increased NRM after ASCT [10-12]. In particular, reactivation of CMV is the leading cause amongst virus-induced morbidity and mortality after ASCT. In transplantations with CMV-seropositive donor or recipient, $60-70 \%$ of patients will develop CMV viremia, and $20-30 \%$ will develop symptomatic CMV disease without preemptive treatment [13], and CMV-IgG-positive recipients have an absolute increase in NRM of as much as $40 \%[14,15]$.

In addition to herpes virus infections, human parvovirus B19 (ParvoB19) can persist in several tissues [16] and reactivate after ASCT [17]. ParvoB19 has a pronounced tropism toward erythroid progenitors [18] and most commonly causes anemia. However, in some patients the only sign of reactivation is a cutaneous rash $[19,20]$ also reported to present with a GvHD-like erythema in 2 stem cell recipients [21].

In contrast to GvHD, where treatment is immunosuppressive therapy (IST) [22-24], treatment of viral infection comprises reduction of immunosuppression to support antiviral immune response and in some cases virostatics. Increased immunosuppression is paralleled by an increased risk of simultaneous viral exacerbation with a higher risk to develop a fatal course [25]. Thus, exact delineation of the etiology of a skin rash is important to establish correct treatment of skin rash after ASCT and may lead to reduced NRM.

However, making a distinction between aGvHD of the skin and the competing diagnoses is difficult and mainly based on clinical findings, as no specific diagnostic markers for aGvHD are established [6]. The diagnostic value of skin histopathology is limited by the lack of specific diagnostic criteria [26]. Histopathology was not associated with clinical diagnosis, clinical severity, and outcome of aGvHD in several studies [27-29]. Experts estimate sensitivity and specificity of histopathological examination for diagnosis of acute GvHD to only reach 0.73 and 0.66 , respectively [30].

The detection of virus genome in affected skin after ASCT might help to reveal the underlying etiology of the rash. It also might be associated with the clinical course and NRM in patients with skin rash after ASCT. Polymerase chain reaction (PCR)-based assays are able to detect virus genome in skin affected by herpes and parvoB19 viruses [31-33].

This study aimed to evaluate the rate of virus DNApositive skin biopsies for CMV, EBV, HHV6, HHV8, HSV, VZV, and ParvoB19 in biopsies of acute skin rashes after ASCT. We further investigated, if detection of herpesvirus- or ParvoB19-DNA helps to define the etiology of the exanthema. Associations between skin virus PCR results and clinical presentation at occurrence of exanthema, immunosuppressive and antiviral treatments, further clinical course, and NRM were investigated. We examined the association between histological and DNA test results from skin as well as between DNA test results from skin and blood. These analyses will help to elucidate if there might be a role of virus genome analyses in skin for diagnosis, prediction of the clinical course, and treatment in skin rashes after ASCT.

\section{Methods}

Patients and Transplant Procedures

We retrospectively screened all adult patients who underwent ASCT for hematological malignancies or aplastic anemia at the University Hospital Halle between May 2005 and December 2013. We identified and characterized those patients with exanthema occurring 0-100 days after ASCT. All patients received their first ASCT. Transplant procedures and GvHD prophylaxis were performed according to institutional standards. All patients received acyclovir prophylaxis. All data were extracted by reviewing patient charts and physician reports.

\section{Diagnostic and Treatment at the Time of Exanthema}

Occurrence

In the case of exanthema, skin biopsies were taken by $4 \mathrm{~mm}$ punch biopsies including cutis and subcutis. Histopathological analyses were done on formalin-embedded tissue. Multiplex virus PCR analysis of skin was performed from a second punch on tissue stored in $0.9 \%$ saline after repetitive washing. Commercially available kits were used for PCR against CMV: Quiagen Artus 4503265, EBV: Quiagen Artus 4501065, HHV6: Tib molbiol 40-0282-32, HHV8: Tib molbiol 05945224 001, HSV: Quiagen Artus 4500065, VZV: Quiagen Artus 4502065, Parvovirus B19: Roche 03-246-809001 according to the manufacturers' guidelines. As quantification is not validated for skin tissue analyses, we used dichotomized positive/negative categories as test results. To analyze whether a viremia at the time of occurrence of exanthema was present, virus PCR analyses for CMV, EBV, HHV6 and PavoB19 from blood drawn concomitantly with the skin biopsy (+/-10 days) were assessed.

In available cases, immunohistochemistry against CMV (Dako, clone CCH2, EBV LMP1 (Dako, clone CS.1-4) and ParvoB19 (Abcam, clone R92F6) was performed according to diagnostic standard protocols. 


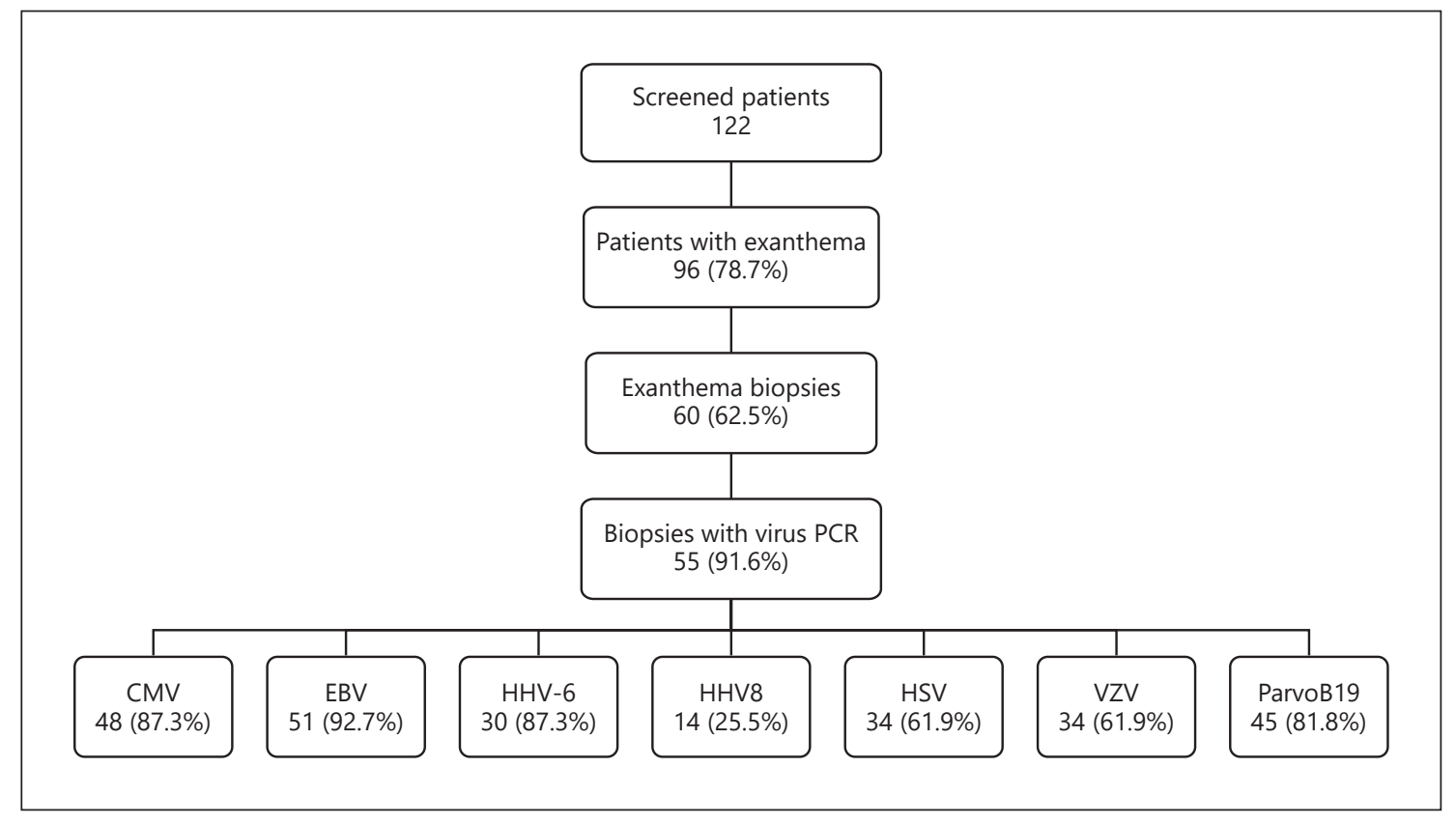

Fig. 1. Patient flow. CMV, cytomegalovirus; EBV, Epstein-Barr virus; HHV6, herpes virus 6; HHV8, herpes virus 8; HSV, herpes simplex virus; ParvoB19, parvovirus B19; PCR, polymerase chain reaction; VZV, varicella zoster virus.

Treatment decisions regarding immunosuppressive and antiviral therapy (IST and AVT) were recorded. AVT was administered according to our institutional guidelines: for CMV, HHV6 and HHV8 ganciclovir $5 \mathrm{mg} / \mathrm{kg}$ b.i.d. intravenously for 14 days followed by a 14-day maintenance with valganciclovir. HSV and VZV reactivation/infection were treated with intravenous acyclovir $800 \mathrm{mg} 5$ times per day for 7 days followed by reinitiation of acyclovir prophylaxis. For 2 consecutive EBV viremia above 10,000 copies/mL plasma, Rituximab $375 \mathrm{mg} / \mathrm{m}^{2}$ was administered. In addition, all virus reactivations/infections were treated with $30 \mathrm{~g}$ intravenous immunoglobulins.

Definitions, End Points, and Statistical Analysis

Positive virus PCR was defined as positive test result according to the manufacturers' definition and negative virus PCR as a sample with negative PCR for all analyzed viruses in the sample. Acute GvHD was staged and graded according to the modified Glucksberg criteria $[34,35]$. Recorded additional clinical signs at time of biopsy were fever, fatigue, hepatosplenomegaly, or lymph node enlargement. Modification of IST was defined as increased dose or initiation of IST due to exanthema. The initiation of antiviral agents such as virostatics, intravenous immunoglobulins or B-celldepleting agents (e.g., rituximab) was recorded and summarized as AVT. NRM was defined as death due to any cause except relapse or disease progression. Patients were censored after death due to the underlying disease or end of follow-up.

Relationships between variables were investigated by bivariate analyses. Nominal or ordinal variables with multiple categories were condensed to binominal variables for comparison. Testing of association of binominal variables was done by $\chi^{2}$ or Fisher's exact test as appropriate. Pearson $t$ test was used to compare metric data between groups. Kaplan-Meier plots visualized the cumulative incidences of the NRM and statistical comparisons between groups were done by log-rank tests. Cox proportional hazard models were used for multivariate survival analysis regarding NRM. A two-sided $p$ value $<0.05$ was regarded as significant.

\section{Results}

Patient Characteristics and Skin Virus PCR Analyses

Ninety-six of the 122 patients (78.7\%) who underwent ASCT developed an exanthema after transplantation. Out of these patients, 55 (56.9\%) received a skin biopsy with histopathological and concomitant PCR analysis of viral genome for CMV $(n=48)$, EBV $(n=51)$, HHV6 $(n=30)$, HHV8 $(n=34), \operatorname{HSV}(n=34), \operatorname{VZV}(n=23)$, and ParvoB19 ( $n=45$; Fig. 1$)$. Patient and transplant characteristics did not significantly differ between patients with exanthema who received or did not receive a skin biopsy (Table 1). Median duration of follow-up of the patients with virus PCR-analyses from skin was 516 days (interquartile range 176-1,449).

Viral genome was detected in $23(41.8 \%)$ of the 55 biopsies (Table 2). PCR analyses were positive in 6 of 48 cases (12.5\%) for CMV, 6 of 51 cases for EBV (11.8\%), 3 of 30 cases for HHV6 (10\%), 0 of 14 cases for HHV8, 0 of 


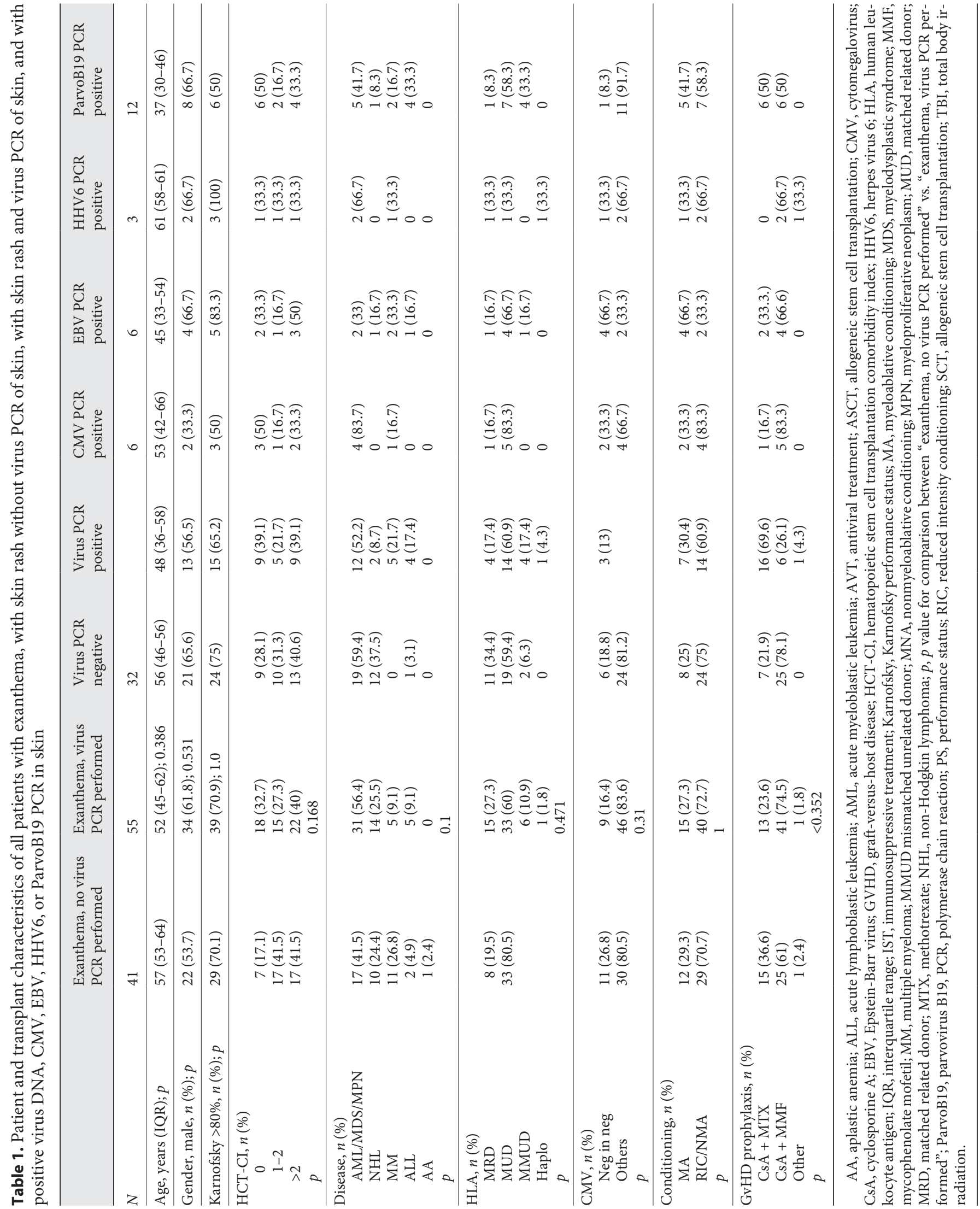


Table 2. Virus PCR analyses of skin biopsies in exanthema after SCT

\begin{tabular}{llllccccc}
\hline PCR & All viruses & CMV & EBV & HHV6 & HHV8 & HSV & VZV & ParvoB19 \\
\hline Analyzed, $n$ & 55 & 48 & 51 & 30 & 14 & 34 & 34 & 45 \\
Positive, $n(\%)$ & $23(41.8)$ & $6(12.5)$ & $6(11.8)$ & $3(10)$ & 0 & 0 & $1(2.9)$ & $12(26.7)$ \\
Negative, $n(\%)$ & $32(58.2)$ & $42(87.5)$ & $45(88.2)$ & $27(90)$ & $14(100)$ & $34(100)$ & $33(97.1)$ & $33(73.3)$ \\
\hline
\end{tabular}

CMV, cytomegalovirus; EBV, Epstein-Barr virus; HHV6, herpes virus 6; HHV8, human herpes virus 8; HSV, herpes simplex virus; $n$, number; ParvoB19, parvovirus B19; PCR, polymerase chain reaction; VZV, varicella zoster virus.

Table 3. Associations between result of virus PCR of skin and histopathology of skin rash biopsies

\begin{tabular}{|c|c|c|c|c|c|c|c|c|c|c|}
\hline & \multicolumn{2}{|c|}{ Virus PCR $(n=55)$} & \multicolumn{2}{|c|}{ CMV PCR $(n=48)$} & \multicolumn{2}{|c|}{ EBV PCR $(n=51)$} & \multicolumn{2}{|c|}{ HHV6 PCR $(n=30)$} & \multicolumn{2}{|c|}{ ParvoB19 PCR $(n=45)$} \\
\hline & positive & negative & positive & negative & positive & negative & positive & negative & positive & negative \\
\hline Histo other, $n$ & 17 & 28 & 5 & 34 & 5 & 37 & 1 & 23 & 9 & 28 \\
\hline GvHD & 11 & 19 & 3 & 24 & 2 & 26 & 0 & 16 & 6 & 18 \\
\hline Drug toxicity & 2 & 3 & 0 & 3 & 1 & 4 & 0 & 2 & 1 & 3 \\
\hline$p$ & 0.29 & & 0.477 & & 0.268 & & 0.061 & & 0.443 & \\
\hline
\end{tabular}

CMV, cytomegalovirus; EBV, Epstein-Barr virus; HHV6, herpes virus 6; $n$, number; $p$, $p$ value; ParvoB19, parvovirus B19; PCR, polymerase chain reaction.

34 cases for HSV, 1 of 34 cases for VZV (2.9\%), and 12 of 45 cases for ParvoB19 (26.7\%). Two patients had positive PCR for both EBV and ParvoB19, and 1 patient had positive PCR for CMV, EBV, VZV, and ParvoB19. Due to the small number of positive tests for VZV, HSV, and HHV8, these viruses were not included in further analyses.

Comparison of Results from Skin Virus PCR, Skin

Histopathology, and Immunohistochemistry

In an analysis including all studied viruses, no association between PCR result and histopathological diagnosis was seen $(p=0.29)$. Out of the 23 patients with detection of viral DNA in skin, 6 patients had histopathological diagnosis of viral exanthema, whereas 17 patients had different diagnoses ( $11 \mathrm{aGvHD}, 2$ drug-induced skin alterations, 3 equivocal skin alterations, 1 normal skin). Four of the 32 patients with negative virus PCR from skin had histopathological diagnosis of virus exanthema. Separate analyses for the CMV, EBV, HHV6, and ParvoB19 subgroups did not reveal an association between PCR-based detection of viral DNA and histopathological diagnosis of exanthema (Table 3).

All cases with negative PCR were also immunohistochemistry negative for CMV (7/7), EBV (10/10), and Par-
voB19 (6/6). Two of 3 cases with positive skin CMV PCR were immunohistochemistry positive. No EBV or ParvoB19 PCR-positive case was available for immunohistochemistry.

\section{Comparison of Results from Skin Virus PCR and Blood Virus PCR}

We identified 45, 46, 10, and 13 patients with concomitant PCR analysis from skin and blood for CMV, EBV, HHV6, and ParvoB19. PCR results from skin and blood were associated with $\operatorname{CMV}(p=0.016), \operatorname{EBV}(p<0.001)$, and HHV6 $(p=0.067)$. For Parvo19, PCR from blood was negative in every case, and no association between skin and blood PCR was noticed (Table 4).

\section{Association between Results of PCR from Skin,}

Exanthema Characteristics, and Treatment

No significant differences regarding exanthema characteristics were identified when patients with negative virus PCR were compared to patients with positive PCR for any single or particular viruses (Table 5). IST was started in 26 of 32 patients without positive virus PCR versus 5 of 12 patients with positive ParvoB19-PCR $(p=0.023)$. Antiviral treatment (AVT) was started in 5 of 32 patients 
Table 4. Associations between results of virus PCR in skin and virus PCR in blood

\begin{tabular}{|c|c|c|c|c|c|c|c|c|c|c|}
\hline & \multicolumn{2}{|c|}{$\begin{array}{l}\text { Skin virus PCR } \\
(n=55)\end{array}$} & \multicolumn{2}{|c|}{$\begin{array}{l}\text { Skin CMV PCR } \\
(n=45)\end{array}$} & \multicolumn{2}{|c|}{$\begin{array}{l}\text { Skin EBV PCR } \\
(n=46)\end{array}$} & \multicolumn{2}{|c|}{$\begin{array}{l}\text { Skin HHV6 PCR } \\
(n=10)\end{array}$} & \multicolumn{2}{|c|}{$\begin{array}{l}\text { Skin ParvoB19 PCR } \\
(n=13)\end{array}$} \\
\hline & positive & negative & positive & negative & positive & negative & positive & negative & positive & negative \\
\hline Blood virus PCR positive & 18 & 11 & 4 & 6 & 6 & 7 & 2 & 1 & 0 & 0 \\
\hline Blood virus PCR negative & 5 & 21 & 2 & 33 & 0 & 33 & 0 & 7 & 3 & 10 \\
\hline$p$ & $<0.001$ & & 0.016 & & $<0.001$ & & 0.067 & & n.a. & \\
\hline
\end{tabular}
tion.

CMV, cytomegalovirus; EBV, Epstein-Barr virus; HHV6, herpes virus 6; $n$, number; $p$, $p$ value; ParvoB19, parvovirus B19; PCR, polymerase chain reac-

Table 5. Characteristics of the exanthema and GvHD staging/grading at time of skin rash biopsy; treatment and diagnosis

\begin{tabular}{|c|c|c|c|c|c|c|}
\hline & $\begin{array}{l}\text { Virus PCR } \\
\text { negative }\end{array}$ & $\begin{array}{l}\text { Virus PCR } \\
\text { positive }\end{array}$ & $\begin{array}{l}\text { CMV PCR } \\
\text { positive }\end{array}$ & $\begin{array}{l}\text { EBV PCR } \\
\text { positive }\end{array}$ & $\begin{array}{l}\text { HHV6 PCR } \\
\text { positive }\end{array}$ & $\begin{array}{l}\text { ParvoB19 PCR } \\
\text { positive }\end{array}$ \\
\hline$N$ & 32 & 23 & 6 & 6 & 3 & 12 \\
\hline $\begin{array}{l}\text { Time after ASCT, median (min-max), } \\
\text { days; } p\end{array}$ & $23(15-44)$ & $37(20-100) ; 0.886$ & 47.5 (13-143); 0.807 & $41(19-70) ; 0.807$ & 130 (n.a.); n.a. & 32 (14-80); 0.54 \\
\hline $\begin{array}{l}\text { Time from exanthema to biopsy, } \\
\text { median (min-max), days; } p\end{array}$ & $3(1-15)$ & $2(1-12) ; 0.36$ & $3(0-12) ; 0.624$ & $6(1-23) ; 0.682$ & 4 (n.a.); 0.178 & $2(1-12) ; 0.373$ \\
\hline $\begin{array}{l}\text { GvHD overall grade at biopsy, } n(\%) \\
\quad \leq \text { II } \\
\quad>\text { II } \\
\quad p\end{array}$ & $\begin{array}{l}31(96.9) \\
1(3.1)\end{array}$ & $\begin{array}{l}22(95.7) \\
1(4.3) \\
1\end{array}$ & $\begin{array}{l}6(100) \\
0 \\
1\end{array}$ & $\begin{array}{l}6(100) \\
0 \\
1\end{array}$ & $\begin{array}{l}3(100) \\
0 \\
1\end{array}$ & $\begin{array}{c}11(91.7) \\
1(8.3) \\
0.476\end{array}$ \\
\hline Further symptoms ${ }^{\mathrm{a}}$ present, $n(\%) ; p$ & $12(37.5)$ & $7(30.4) ; 0.775$ & $1(16.7) ; 0.643$ & $3(50 \%) ; 0.663$ & $1(33.3) ; 1.0$ & $5(41.7) ; 1.0$ \\
\hline $\begin{array}{l}\text { IST increased or newly introduced, } \\
n(\%) ; p\end{array}$ & $26(81.3)$ & $12(52.2) ; 0.037$ & $3(50) ; 0.131$ & $3(50) ; 0.131$ & $2(66.8) ; 0.499$ & $5(41.7) ; 0.023$ \\
\hline $\begin{array}{l}\text { AVT increased or newly introduced, } \\
n(\%) ; p\end{array}$ & $5(15.6)$ & $13(56.5) ; 0.003$ & $5(83.3) ; 0.003$ & $6(100) ;<0.001$ & $3(100) ; 0.009$ & $3(25) ; 0.663$ \\
\hline $\begin{array}{l}\text { Response of exanthema to treatment } \mathrm{t}^{\mathrm{b}} \text {, } \\
n(\%) ; p\end{array}$ & $26(81.3)$ & $20(87) ; 0.72$ & $5(83.3) ; 1.0$ & $5(83.3) ; 1.0$ & $3(100) ; 1.0$ & $7(58.3) ; 0.653$ \\
\hline $\begin{array}{l}\text { AVT, antiviral treatment; ASCT, all } \\
\text { ease; HHV6, herpes virus 6; IST, immur } \\
\text { B19; PCR, polymerase chain reaction. }{ }^{a} \text { I } \\
\text { defined as alive and no secondary IST in }\end{array}$ & $\begin{array}{l}\text { leic stem } \\
\text { opressive } \\
\text { er symptc }\end{array}$ & $\begin{array}{l}\text { insplantation; CM } \\
\text { ient; } n \text {, number; } p \text {, } \\
\text { ever, fatigue, hepat }\end{array}$ & $\begin{array}{l}\text { cytomegalovirus; } \mathrm{E} \\
\text { value for compariso } \\
\text { splenomegaly or lym }\end{array}$ & $\begin{array}{l}\text { Epstein-Barr vi } \\
\text { gainst group "vir } \\
\text { hode enlargeme }\end{array}$ & $\begin{array}{l}\text { GVHD, acute } \\
\text { CR negative"; } \\
\text { Response of ex }\end{array}$ & $\begin{array}{l}\text { aft-versus-host d } \\
\text { rvoB19, parvovir } \\
\text { thema to treatme }\end{array}$ \\
\hline
\end{tabular}

with negative virus PCR; all of these 5 patients had systemic herpesvirus reactivation. In comparison, 5 of 6 patients with positive CMV-PCR $(p=0.003), 6$ of 6 patients with positive EBV-PCR $(p<0.001)$, and 3 of 3 patients with positive HHV6-PCR $(p=0.009)$ were started on AVT.

Parvovirus B19 and Herpesvirus PCR in Skin Rash after Allogeneic SCT
Association of Results from Skin Virus PCR with NRM NRM did not differ between patients with negative versus positive skin PCR for either CMV $(p=0.2)$, EBV $(p=0.259)$, or HHV6 $(p=0.208)$. In contrast, patients with PavoB19 PCR-positive exanthemas had a lower NRM (NRM-free survival not reached) than patients with 


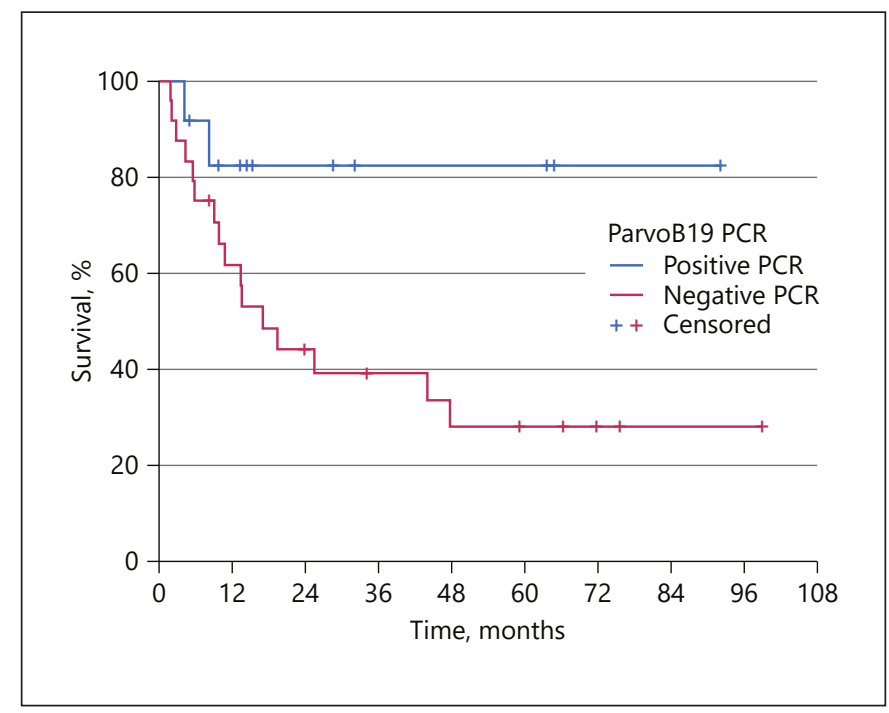

Fig. 2. Transplant-related mortality for virus PCR-negative vs. -positive skin rash for ParvoB19 (negative, $n=24$, vs. positive, $n=$ $12 ; p=0.041)$. ParvoB19, parvovirus B19; PCR, polymerase chain reaction.

negative PCR for any of the tested viruses (median NRMfree survival 16.9 months; $p=0.041$; Fig. 2). The 12 patients with positive PCR for ParvoB19 tended to have lower maximal extent of exanthema than the 36 with negative PCRs (stage $1-2: 66.7$ vs. $41.4 \%, p=0.289$ ) and had fewer initiations of IST (no IST: 58.3 vs. $16.7 \%, p=0.015$ ).

We performed a multivariate analysis including ParvoB19 skin PCR results, grade of aGvHD, initiation of IST, donor/recipient CMV serostatus, HLH-match, conditioning intensity, and HCT-CI. Detection of ParvoB19 DNA and GvHD grade III-IV were significant predictors of TRM in this analysis (Table 6). In contrast, initiation of IST, CMV serostatus, HLA-match, HCT-CI, and conditioning intensity did not remain significantly associated with NRM.

Regarding the causes of death, 6 (50\%) of the 12 patients with positive ParvoB19 died; 4 died due to relapse of the malignant disease (67\%) and 2 due to NRM (33\%). Of the 24 patients with negative PCRs for ParvoB19 and other viruses, 18 (75\%) died. Of these, 2 died due to relapse of the malignant disease (11\%), but 16 died due to NRM (89\%).

\section{Discussion}

To our best of our knowledge, this is the first study evaluating the incidence and the clinical relevance of positive PCR for herpesviruses and ParvoB19 in skin rash
Table 6. Multivariate analysis for NRM risk factors

\begin{tabular}{llll}
\hline Variable & Categories & HR $(95 \% \mathrm{CI})$ & $\begin{array}{l}p \\
\text { value }\end{array}$ \\
\hline ParvoB19 DNA detection & No vs. yes & $0.12(0.02-0.7)$ & 0.019 \\
\hline GvHD grade & I-II & $5.11(1.5-17)$ & 0.008 \\
& vs. III-IV & & \\
\hline Initiation of IST & No vs. yes & $1.20(0.3-4.7)$ & 0.845 \\
\hline HCT-CI & 0 vs. > =1 & $0.48(0.2-1.5)$ & 0.209 \\
\hline CMV serostatus & $\begin{array}{l}\text { Neg in neg } \\
\text { vs. other }\end{array}$ & $4.50(0.9-22)$ & 0.067 \\
\hline HLA & $\begin{array}{l}10 / 10 \text { ident } \\
\text { vs. other }\end{array}$ & $1.76(0.3-9.8)$ & 0.516 \\
\hline Conditioning intensity & MA vs. other & $0.06(0.1-1)$ & 0.058 \\
\hline
\end{tabular}

CI, confidence interval; CMV, cytomegalovirus; GvHD, graftversus-host disease; HCT-CI, hematopoietic stem cell transplantation comorbidity index; HLA, human leukocyte antigen; HR, hazard ratio; IST, immunosuppressive therapy; MA, myeloablative; PCR, polymerase chain reaction; ParvoB19, parvovirus B19.

after ASCT. Detection of CMV, EBV, or HHV6 in skin rash was not associated with exanthema presentation, clinical course, or TRM but was strongly associated with systemic reactivation. In contrast, detection of ParvoB19 in skin was not associated with systemic reactivation but was associated with low NRM in uni- and multivariate survival analyses.

Published data on the frequency of the detection of DNA from herpesviruses and ParvoB19 virus in skin rashes until 100 days after ASCT are sparse. Hentrich et al. [33] detected HHV6 in 6 cases and concomitant ParvoB19 in 2 cases of skin rash after ASCT but did not report the frequency of HHV6 and ParvoB19-positive cases. Sawada et al. [36] analyzed 5 biopsies of skin or mucosa with high clinical suspicion for herpes virus infection with a multiplex PCR against HSV1/2, VZV, CMV, EBV, and HHV6. They detected EBV in 2, VZV in 2, and HSV in 1 sample. In the present study, detection of viral DNA in skin rash after ASCT was common with $42 \%$ positive biopsies. Regarding particular viruses, DNA of CMV, EBV, and HHV 6 could be detected in about $12 \%$ of skin biopsies, respectively. In line with the regular acyclovir prophylaxis in the studied cohort, VZV was identified in only 1 rash, and HSV PCR was negative in all samples. PCR for HHV8 was negative in all cases. Serological prevalence of HHV8 in Europe is low and reactivation after ASCT is rare [10]. ParvoB19 was detected in $27 \%$ of the 
exanthemas. Outside of the ASCT setting, ParvoB19 DNA was identified in skin affected by erythema but also in healthy individuals as the virus has the capacity to persist in skin $[31,37]$. Thus, clinical relevance of detection of ParvoB19 DNA in skin biopsies outside of ASCT setting is under debate.

The value of histopathology for diagnosis of acute skin GvHD is limited. This is shown by multiple analyses which did not find an association between histological and definite clinical diagnosis of exanthema [27, 30, 38]. In the present study, diagnoses by histopathology were not associated with the result of the virus PCRs from the skin. Only in 6 out of 17 cases with positive virus PCR, a potential viral etiology of exanthema was reported by histopathology. This might be due to, for example, parallel occurrence of virus infection and GvHD but also due to the limited value of skin virus PCR analyses to identify the pathogenic cause of the rash. Serial biopsies could help to depict the sequence of virus and aGvHD occurrence.

In PCR negative cases, the results of CMV, EBV, and ParvoB19 immunohistochemistry were in concordance with the PCR results. Two of the 3 CMV PCR-positive cases showed positive intraepithelial staining by immunohistochemistry indicating local infection. However, the number of cases is too small to draw conclusions about the association of IHC with PCR. No EBV- and ParvoB19positive case was available for immunohistochemistry.

The comparison of PCR results concomitantly analyzed from skin and blood revealed a strong association for the analyzed Herpesviridae. All cases with positive skin PCR for EBV and HHV6 and $67 \%$ with positive skin PCR for CMV had a positive blood PCR. This can be due to blood contamination of the biopsy by concomitant viremia even if skin was repetitively rinsed with saline before PCR in our analysis. Thus, detection of herpesvirus DNA in exanthematous skin might reflect viremia in some cases and could make skin-specific analysis dispensable. In concordance with that, Hentrich et al. [33] detected HHV6 DNA in the blood of 4 out of 6 patients with HHV6 in skin rash. Virus-specific immunohistochemistry could help to clarify the relevance of blood contamination. In contrast to herpes viruses, ParvoB19 was not detected in blood even if skin biopsy was positive both in our and in a PCR analysis of multiple viruses in repetitive blood samples after ASCT by Inazawa et al. [39].

The present study did not reveal any association of the detection of herpes virus DNA in skin with the clinical presentation of aGvHD or TRM. Further data regarding the value of skin PCR analyses in this setting are lacking. Many studies analyzed the association between virus detection in

Parvovirus B19 and Herpesvirus PCR in Skin Rash after Allogeneic SCT blood and aGvHD or NRM after ASCT. Regarding CMV, GvHD and its treatment with IST is a risk factor for CMV reactivation and disease [40]. On the other hand, CMV infection was linked to increased risk of GvHD in infected tissues [41], and positive pretransplant CMV serostatus of donor and or recipient as well as CMV reactivation after ASCT are associated with a 3-15\% increased NRM [4244]. In line with this, in our analysis, NRM was $55 \%$ in patients without and $63 \%$ in patients with herpesvirus reactivations in peripheral blood (data not shown). The associations between a GvHD and NRM with HHV6 are conflicting. Some studies identified a significant correlation of HHV6 detection with the development of aGvHD and NRM [33, $45]$ but others did not $[46,47]$. Looking at ParvoB19, we found that patients with detection of ParvoB19 DNA in skin had a significantly reduced NRM compared to patients with negative virus PCR. This association remained significant in multivariate survival analysis indicating ParvoB19 detection as an independent prognostic factor. However, the analysis can neither elucidate the pathomechanistic role of ParvoB19 detection nor reliably exclude ParvoB19 DNA detection as a surrogate for other factors associated with low NRM. Irrespective of comparable overall GvHD grade, IST was significantly less often increased or newly introduced in patients with positive ParvoB19 skin PCR. It is not clear if PCR results influenced the initiation of IST as these analyses are hampered by the retrospective design of the study. The pathophysiological relevance of ParvoB19 in skin rash after ASCT is uncertain: virus induced cytopathic effects, the response of allogeneic $\mathrm{T}$ cells to the virus or its residues as well as tissue-specific damage by cross-reactive T cells could subsequently cause the skin rash [48]. On the other hand, and as discussed above, ParvoB19 DNA can also be detected in healthy skin and might be a bystander of skin disease. Additional immunohistochemical studies of PCR-positive cases demonstrating ParvoB19 in endothelial cells of the dermis are needed to pathogenically link ParvoB19 to skin rash mimicking or triggering GvHD. However, detection of ParvoB19 DNA in skin rash helped to identify a subgroup of patients who could benefit from withholding IST. This is in line with the report of 2 patients with self-limiting GvHD-like skin rash and detection of ParvoB19 in affected skin as well as in bone marrow reported by Muetherig et al. [21].

We reported a rate of $79 \%$ of patients with exanthema. Klager et al. [6] reported a rate of 62\% (152 of 243 patients) of skin rashes of any causes, only $17.7 \%$ being due to GvHD after T-cell depleted ASCT. The incidence of GvHD in non-T-cell-depleted ASCT is $40-60 \%$, and about $70 \%$ of these patients have skin involvement [49]. In most studies 
focused on GvHD, skin rashes stage 1 and due to reasons other than GvHD are not reported. Taken together, this indicates a reasonable rate of skin rashes in our study.

During the time of the analysis, virus PCRs were not performed for all skin biopsies. This could have biased the analyses. Furthermore, the kits used are only validated for plasma and whole blood. We therefore decided to evaluate only qualitative test results to exclude methodological bias. Quantitative assessment of viral load by kits validated for skin would help to better identify the relevance of the virus DNA detection, as high viral load in, for example, plasma is associated with morbidity and mortality after ASCT [40].

A detailed clinical description of the exanthema would further help to characterize the skin rashes. Due to the retrospective design, we do not have these data available.

In conclusion, the present study demonstrated that herpes virus DNA can be detected in about $12 \%$ and ParvoB19 DNA in $27 \%$ of skin rash after ASCT. Virus DNA detection was not associated with histological diagnosis or with exanthema characteristics. The strong direct association between PCR results from blood and skin for herpes viruses might reflect viremia. In contrast, detection of ParvoB19 in skin rash after ASCT was not associated with viremia and is associated with fewer IST initiations and decreased NRM; thus, it identifies patients with excellent clinical course. These data provide the rationale to study the relevance of ParvoB19 DNA detection in skin rash after ASCT in larger ASCT cohorts.

\section{Statement of Ethics}

The analysis was performed in accordance with the standards of the local independent review board and the Declaration of Helsinki.

\section{Conflict of Interest Statement}

The authors have no conflicts of interest to declare.

\section{Funding Sources}

The authors received no funding for this study.

\section{Author Contributions}

T.W. designed study, analyzed data, wrote manuscript. A.S. and K.L. collected and analyzed data and wrote the manuscript. M.B. and A.R. performed, evaluated, and interpreted immunohistochemistry and contributed to manuscript writing. L.P.M. designed the study and wrote the manuscript.

\section{References}

1 Bacigalupo A, Sormani MP, Lamparelli T, Gualandi F, Occhini D, Bregante S, et al. Reducing transplant-related mortality after allogeneic hematopoietic stem cell transplantation. Haematologica. 2004 Oct;89(10):123847.

2 Gooley TA, Chien JW, Pergam SA, Hingorani $\mathrm{S}$, Sorror ML, Boeckh M, et al. Reduced mortality after allogeneic hematopoietic-cell transplantation. N Engl J Med. 2010 Nov; 363(22):2091-101.

3 Jalali A, Alimoghaddam K, Mahmoudi M, Mohammad K, Zeraati H, Mousavi SA, et al. The EBMT Risk Score in the Presence of Graft Versus Host Disease in Allogeneic Stem Cell Transplantation in Adult Acute Myelogenous Leukemia: A Multistate Model for Competing Risks. Int J Hematol Oncol Stem Cell Res. 2014 Jul;8(3):1-11.

4 Hill GR, Krenger W, Ferrara JL. The role of cytokines in acute graft-versus-host disease. Cytokines Cell Mol Ther. 1997 Dec;3(4):25766.

5 Rupec RA, Plewig G. [Graft-versus-host disease: a dermatologic view of an interdisciplinary problem]. J Dtsch Dermatol Ges. 2004 Apr;2(4):249-59.
6 Klager S, Lacouture ME, Hannum M, Devlin SM, Maloy M, Pulitzer M, et al. Drugs as a Frequent Cause of Acute Rash in Patients after CD34+-Selected Peripheral Blood Stem Cell Transplantation. Biol Blood Marrow Transplant. 2019 Nov;25(11):2172-80.

7 Akpek G, Joseph R, Günay C, Kessler II, Shvartsbeyn M, Bhatnagar B, et al. Frequent detection of herpes simplex virus antigen in skin and peripheral blood CD34+ mononuclear cells from patients with graft-versushost disease. Biol Blood Marrow Transplant. 2013 Apr;19(4):529-37.

8 Einsele H, Bertz H, Beyer J, Kiehl MG, Runde V, Kolb HJ, et al.; Infectious Diseases Working Party (AGIHO) of the German Society of Hematology and Oncology (DGHO). Infectious complications after allogeneic stem cell transplantation: epidemiology and interventional therapy strategies-guidelines of the Infectious Diseases Working Party (AGIHO) of the German Society of Hematology and Oncology (DGHO). Ann Hematol. 2003 Oct; 82(Suppl 2):S175-85.

9 Yoshikawa T, Ihira M, Ohashi M, Suga S, Asano Y, Miyazaki H, et al. Correlation between HHV-6 infection and skin rash after allogeneic bone marrow transplantation. Bone Marrow Transplant. 2001 Jul;28(1): 77-81.

10 Ljungman P, de la Camara R, Cordonnier C, Einsele H, Engelhard D, Reusser P, et al.; European Conference on Infections in Leukemia. Management of CMV, HHV-6, HHV-7 and Kaposi-sarcoma herpesvirus (HHV-8) infections in patients with hematological malignancies and after SCT. Bone Marrow Transplant. 2008 Aug;42(4):227-40.

11 Styczynski J, Tridello G, Gil L, Ljungman P, Hoek J, Iacobelli S, et al. Impact of Donor Epstein-Barr Virus Serostatus on the Incidence of Graft-Versus-Host Disease in Patients With Acute Leukemia After Hematopoietic Stem-Cell Transplantation: A Study From the Acute Leukemia and Infectious Diseases Working Parties of the European Society for Blood and Marrow Transplantation. J Clin Oncol. 2016 Jul;34(19): 2212-20.

12 Zerr DM, Corey L, Kim HW, Huang ML, Nguy L, Boeckh M. Clinical outcomes of human herpesvirus 6 reactivation after hematopoietic stem cell transplantation. Clin Infect Dis. 2005 Apr;40(7):932-40. 
13 Hebart H, Einsele H. Clinical aspects of CMV infection after stem cell transplantation. Hum Immunol. 2004 May;65(5):432-6.

14 Kröger N, Zabelina T, Krüger W, Renges $\mathrm{H}$, Stute N, Schrum J, et al. Patient cytomegalovirus seropositivity with or without reactivation is the most important prognostic factor for survival and treatment-related mortality in stem cell transplantation from unrelated donors using pretransplant in vivo T-cell depletion with anti-thymocyte globulin. Br J Haematol. 2001 Jun;113(4):1060-71.

15 Schmidt-Hieber M, Labopin M, Beelen D, Volin L, Ehninger G, Finke J, et al. CMV serostatus still has an important prognostic impact in de novo acute leukemia patients after allogeneic stem cell transplantation: a report from the Acute Leukemia Working Party of EBMT. Blood. 2013 Nov;122(19):3359-64.

16 Söderlund-Venermo M, Hokynar K, Nieminen J, Rautakorpi H, Hedman K. Persistence of human parvovirus B19 in human tissues. Pathol Biol (Paris). 2002 Jun;50(5):307-16.

17 Gama BE, Emmel VE, Oliveira-Silva M, Gutiyama LM, Arcuri L, Colares M, et al. Parvovirus B19 in the Context of Hematopoietic Stem Cell Transplantation: Evaluating Cell Donors and Recipients. Transplant Direct. 2017 Oct; 3(11):e217.

18 Brown KE, Young NS. Parvovirus B19 infection and hematopoiesis. Blood Rev. 1995 Sep; 9(3):176-82.

19 Eid AJ, Brown RA, Patel R, Razonable RR. Parvovirus B19 infection after transplantation: a review of 98 cases. Clin Infect Dis. 2006 Jul; 43(1):40-8.

20 Florea AV, Ionescu DN, Melhem MF. Parvovirus B19 infection in the immunocompromised host. Arch Pathol Lab Med. 2007 May; 131(5): 799-804.

21 Muetherig A, Christopeit M, Müller LP, Grothe W, Weber T, Theurich S, et al. Human parvovirus B19 infection with GvHD-like erythema in two allogeneic stem cell transplant recipients. Bone Marrow Transplant. 2007 Mar; 39(5):315-6.

22 Häusermann P, Walter RB, Halter J, Biedermann BC, Tichelli A, Itin P, et al. Cutaneous graft-versus-host disease: a guide for the dermatologist. Dermatology. 2008;216(4):287-304.

23 Hockenbery DM, Cruickshank S, Rodell TC, Gooley T, Schuening F, Rowley S, et al. A randomized, placebo-controlled trial of oral beclomethasone dipropionate as a prednisone-sparing therapy for gastrointestinal graft-versushost disease. Blood. 2007 May; 109(10): 4557-63.

24 Ringdén O, Uzunel M, Rasmusson I, Remberger M, Sundberg B, Lönnies H, et al. Mesenchymal stem cells for treatment of therapy-resistant graft-versus-host disease. Transplantation. 2006 May;81(10):1390-7.

25 Landgren O, Gilbert ES, Rizzo JD, Socié G, Banks PM, Sobocinski KA, et al. Risk factors for lymphoproliferative disorders after allogeneic hematopoietic cell transplantation. Blood. 2009 May;113(20):4992-5001.
26 Ziemer M, Haeusermann P, Janin A, Massi D, Ziepert M, Wolff D, et al. Histopathological diagnosis of graft-versus-host disease of the skin: an interobserver comparison. J Eur Acad Dermatol Venereol. 2014 Jul;28(7):915-24.

27 Kohler S, Hendrickson MR, Chao NJ, Smoller BR. Value of skin biopsies in assessing prognosis and progression of acute graft-versus-host disease. Am J Surg Pathol. 1997 Sep;21(9):988-96.

28 Hogenes MC, Te Boome LC, van der Valk DC, van Dijk MR, de Weger RA, Kuball J, et al. Clinical versus histological grading in the assessment of cutaneous graft versus host disease. Eur J Med Res. 2019 Apr;24(1):19.

29 Haimes H, Morley KW, Song H, Okhovat JP, Schmidt B, Huang JT. Impact of skin biopsy on the management of acute graft-versus-host disease in a pediatric population. Pediatr Dermatol. 2019 Jul;36(4):455-9.

30 Firoz BF, Lee SJ, Nghiem P, Qureshi AA. Role of skin biopsy to confirm suspected acute graftvs-host disease: results of decision analysis. Arch Dermatol. 2006 Feb;142(2):175-82.

31 Aravindh R, Saikia UN, Mishra B, Kumari V, Sarkar S, Sharma M, et al. Persistence of human parvovirus B19 in tissues from adult individuals: a comparison with serostatus and its clinical utility. Arch Virol. 2014 Sep;159(9):2371-6.

32 Bonvicini F, La Placa M, Manaresi E, Gallinella G, Gentilomi GA, Zerbini M, et al. Parvovirus b19 DNA is commonly harboured in human skin. Dermatology. 2010;220(2):138-42.

33 Hentrich M, Oruzio D, Jäger G, Schlemmer M, Schleuning M, Schiel X, et al. Impact of human herpesvirus- 6 after haematopoietic stem cell transplantation. Br J Haematol. 2005 Jan; 128(1):66-72.

34 Glucksberg H, Storb R, Fefer A, Buckner CD, Neiman PE, Clift RA, et al. Clinical manifestations of graft-versus-host disease in human recipients of marrow from HL-A-matched sibling donors. Transplantation. 1974 Oct;18(4): 295-304.

35 Harris AC, Young R, Devine S, Hogan WJ, Ayuk F, Bunworasate U, et al. International, Multicenter Standardization of Acute Graftversus-Host Disease Clinical Data Collection: A Report from the Mount Sinai Acute GVHD International Consortium. Biol Blood Marrow Transplant. 2016 Jan;22(1):4-10.

36 Sawada A, Koyama-Sato M, Yasui M, Kondo O, Ishihara $\mathrm{T}$, Takeshita $\mathrm{Y}$, et al. Multiplex polymerase chain reaction for six herpesviruses after hematopoietic stem cell transplantation. Pediatr Int. 2011 Dec;53(6):1010-7.

37 Santonja C, Santos-Briz A, Palmedo G, Kutzner $\mathrm{H}$, Requena L. Detection of human parvovirus B19 DNA in 22\% of 1815 cutaneous biopsies of a wide variety of dermatological conditions suggests viral persistence after primary infection and casts doubts on its pathogenic significance. Br J Dermatol. 2017 Oct;177(4):1060-5.

38 Zhou Y, Barnett MJ, Rivers JK. Clinical significance of skin biopsies in the diagnosis and management of graft-vs-host disease in early postallogeneic bone marrow transplantation. Arch Dermatol. 2000 Jun;136(6):717-21.
39 Inazawa N, Hori T, Hatakeyama N, Yamamoto M, Yoto Y, Nojima M, et al. Large-scale multiplex polymerase chain reaction assay for diagnosis of viral reactivations after allogeneic hematopoietic stem cell transplantation. J Med Virol. 2015 Aug;87(8):1427-35.

40 Hill JA, Mayer BT, Xie H, Leisenring WM, Huang ML, Stevens-Ayers T, et al. The cumulative burden of double-stranded DNA virus detection after allogeneic HCT is associated with increased mortality. Blood. 2017 Apr;129(16): 2316-25.

41 Cantoni N, Hirsch HH, Khanna N, Gerull S, Buser A, Bucher C, et al. Evidence for a bidirectional relationship between cytomegalovirus replication and acute graft-versus-host disease. Biol Blood Marrow Transplant. 2010 Sep;16(9): 1309-14.

42 Green ML, Leisenring WM, Xie H, Walter RB, Mielcarek M, Sandmaier BM, et al. CMV reactivation after allogeneic HCT and relapse risk: evidence for early protection in acute myeloid leukemia. Blood. 2013 Aug;122(7):1316-24.

43 Takenaka K, Nishida T, Asano-Mori Y, Oshima K, Ohashi K, Mori T, et al. Cytomegalovirus Reactivation after Allogeneic Hematopoietic Stem Cell Transplantation is Associated with a Reduced Risk of Relapse in Patients with Acute Myeloid Leukemia Who Survived to Day 100 after Transplantation: The Japan Society for Hematopoietic Cell Transplantation Transplantation-related Complication Working Group. Biol Blood Marrow Transplant. 2015 Nov;21(11):2008-16.

44 Teira P, Battiwalla M, Ramanathan M, Barrett AJ, Ahn KW, Chen M, et al. Early cytomegalovirus reactivation remains associated with increased transplant-related mortality in the current era: a CIBMTR analysis. Blood. 2016 May; 127(20):2427-38.

45 Aoki J, Numata A, Yamamoto E, Fujii E, Tanaka M, Kanamori H. Impact of Human Herpesvirus-6 Reactivation on Outcomes of Allogeneic Hematopoietic Stem Cell Transplantation. Biol Blood Marrow Transplant. 2015 Nov; 21(11):2017-22.

46 Kadakia MP, Rybka WB, Stewart JA, Patton JL, Stamey FR, Elsawy M, et al. Human herpesvirus 6: infection and disease following autologous and allogeneic bone marrow transplantation. Blood. 1996 Jun;87(12):5341-54.

47 Wang FZ, Dahl H, Linde A, Brytting M, Ehrnst A, Ljungman P. Lymphotropic herpesviruses in allogeneic bone marrow transplantation. Blood. 1996 Nov;88(9):3615-20.

48 Fuji S, Kapp M, Einsele H. Alloreactivity of virus-specific $\mathrm{T}$ cells: possible implication of graft-versus-host disease and graft-versus-leukemia effects. Front Immunol. 2013 Oct;4:330.

49 Ratanatharathorn V, Nash RA, Przepiorka D, Devine SM, Klein JL, Weisdorf D, et al. Phase III study comparing methotrexate and tacrolimus (prograf, FK506) with methotrexate and cyclosporine for graft-versus-host disease prophylaxis after HLA-identical sibling bone marrow transplantation. Blood. 1998 Oct;92(7): 2303-14. 